\title{
DEALING WITH SOIL VARIABILITY: SOME INSIGHTS FROM LAND DEGRADATION RESEARCH IN CENTRAL SPAIN
}

\author{
C. FITZJOHN, J. L. TERNAN, A. G. WLLIAMS, A. PEREZ-GONZALEZ AND S. DE ALBA
}

\begin{abstract}

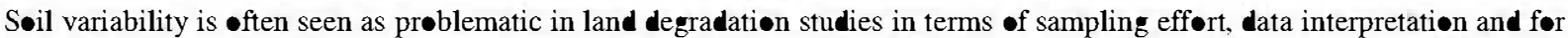

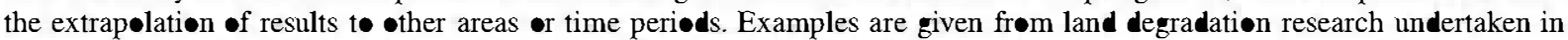

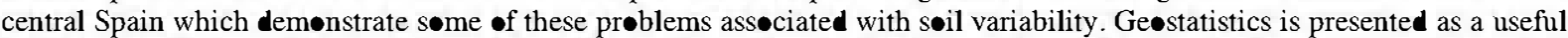

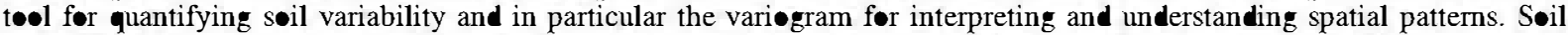
variability is alsø seen to complicate the issues surrøunding management strategies and makes møn॰specific management strategies less likely t• be successful. In recent years several studies have suggested that variability in søil prøperties and

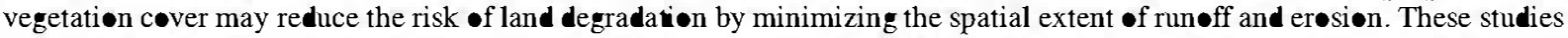

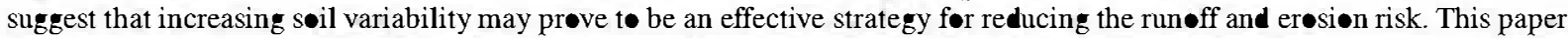

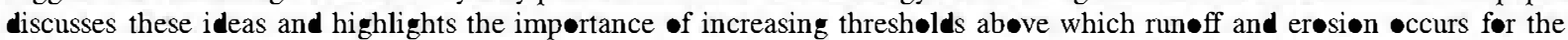
success of such strategies. This in particular applies t• many semiarid envirøments where threshølds are deemed to be extremely løw. Finally, these concepts are placed in the context of scale where søil variability may be viewed as existing at a multitude of nested levels varying frøm the micrø- to the macre-scale.
\end{abstract}

KEY WORDS: $\quad$ soil variability; geostatistics; thresholds; scale; land management; sustainability

\section{NTRODUCTION}

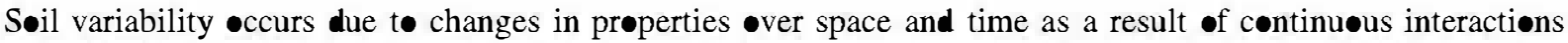
between the lithøsphere, biøsphere and atmosphere (Røwell, 1994). In arid and semi-arid regions variability in søil

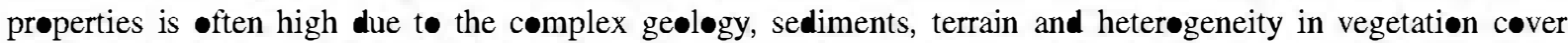
encountered (Yair and Lavee, 1985; Berndtsson and Larson, 1987). This 'natural' variability can be further increase by human disturbance, in particular thrøugh the $\bullet$ nset $\bullet$ degradatiønal gemørphic prøcesses such as søil erøsion and gullying which can increase søil variability through the re-mixing of sediments and exp॰sure of underlying sediments by gully dissection (Beckett and Webster, 1971). For these regions in particular, søil variability is $\bullet$ ften seen as being prøblematic for scientific research (McBratney, 1992). In terms of sampling eff॰rt the more variability that is encountered the greater the number of samples needed to unravel the complexity. In

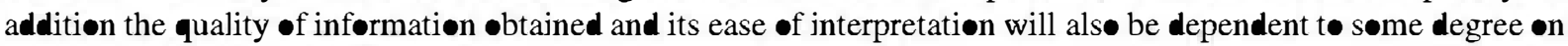
the extent of søil variability encountered by the investigation. Since most scientific research is constrained by a budget and a time period, the degree of variability encountered can determine the nature of the sampling strategy used and the scale at which the study is undertaken. Variability is alsø prøblematic when trying tø transfer research 
findings and ideas t• areas and time periods $\bullet$ ther than thøse in which the study took place. Shakesby et al. (this vølume) give an example where tempøral variability in degradational processes can mislead interpretations of erøsion hazard when the research is constraine by a limite time period. Søil variability als has implications for land management and the success of implemented management strategies. The more uniform a søil is, the easier it is to manage and the less complex the management strategy needs t• be (McBratney, 1992). Where søil variability is complex, a single monøspecific management strategy is likely to have limite success. It is therefore becoming increasingly recognize that in envirøments exhibiting high soil variability that land managers need t• adopt a management apprøach which is søil specific or spatially sensitive (Røbert, 1993). The spatially sensitive

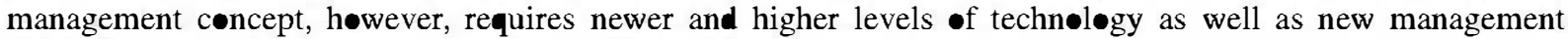

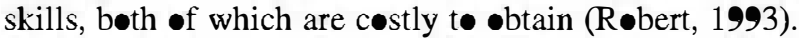

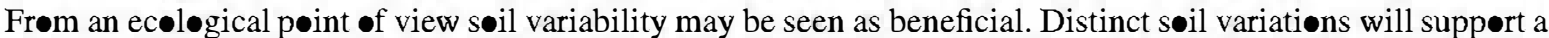
diversity of ecøsystems, increasing the ecøløgical value of a region (Ibanez et al., 1995). Furthermøre, such diversity is considered beneficial in that it promotes stability and resilience within the environment (McBratney, 1992). In recent years several authors have shown that variability in soil properties or vegetation cover may be beneficial for run॰ff and erøsion contrøl (Sharma et al., 1987; Cerdà, 1995; Bergkamp et al., 1996; Fitzjøhn et al., 1998). B॰th Cerdà (1995) and Bergkamp et al. (1996) have shown how a patchiness in vegetation cover can reduce the amount $\bullet$ run॰ff and sediment reaching the base of sløpes and channels. Fitzjøhn et al. (1998) have suggested that spatial variability in søil properties may create a mosaic pattern of areas with contrasting hydrølogical

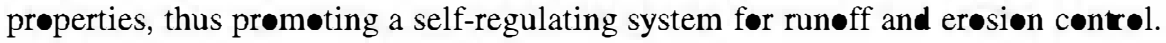

In land degradation research søil variability can be clearly seen t॰ be both prøblematic in terms of assessing degradation and formulating management strategies and beneficial in terms of creating a 'natural' mechanism for run॰ff and erøsion contr land enhancing biødiversity. Using case studies $\bullet$ land degradation research undertaken in central Spain, this paper gives søme examples of the prøblems assøciated with søil variability as well as søme methøds for quantifying variability, in particular geøstatistical analysis. The paper alsø examines the concepts

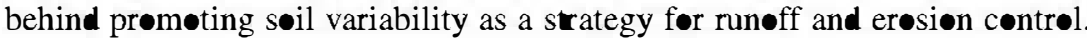

\section{EXAMPLES OF SOL VARIABIITY}

Løcated $70 \mathrm{~km}$ t the nørtheast $\bullet$ Madrid in the Puebla de Valles-Retiendas area $\bullet$ west Guadalajara prøvince, the EU-funded research project BERLIM (EV5V-0041) investigated the erosional impacts of existing and alternative

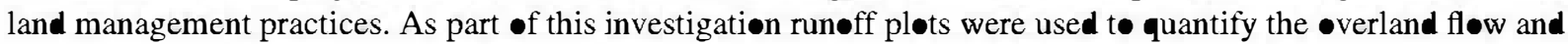

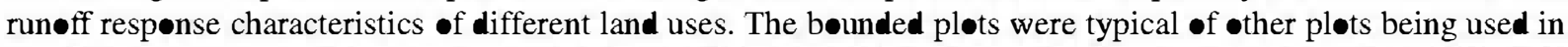
land degradation studies, e.g. MEDALUS, and measured $10 \mathrm{~m}$ in length by $2 \mathrm{~m}$ in width. Tw॰ plots were established in each land use. The plots were aligned with the principle downslope direction and were separated by

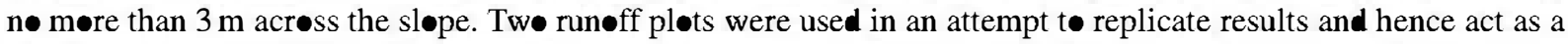
check on data reliability. However, the twø adjacent plots established in the matectal land use showed quite

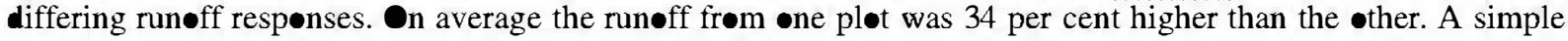

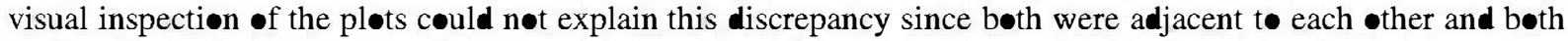
had a dense 100 per cent vegetation cover. The boundaries of the plots were inspected for breaches as were the

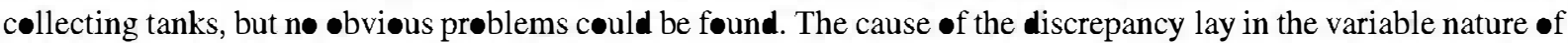
the alluvial sediments underlying the plots (Figure 1). The texture of these sediments varies from horizons dominated by gravels and sand to those dominated by silts and clays (Ternan et al., 1998). Vølumetric søil møisture (20 cm depth) measured using time domain reflectømetry (TDR) was recorded every metre downsløpe within the

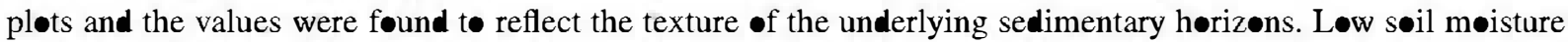

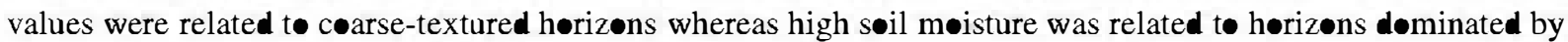
finer sediments. Figure 1 shows the alternating pattern of søil moisture reflecting the interbedded nature of the sediments with søil møisture ranging frøm 16-46 per cent $\bullet$ ver 1-2 m. These interbedded sedimentary hørizøns run

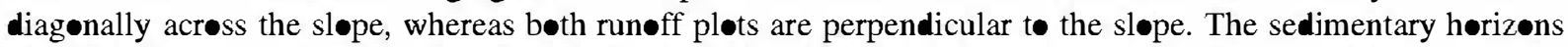

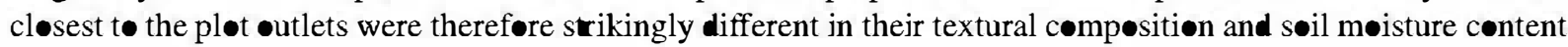




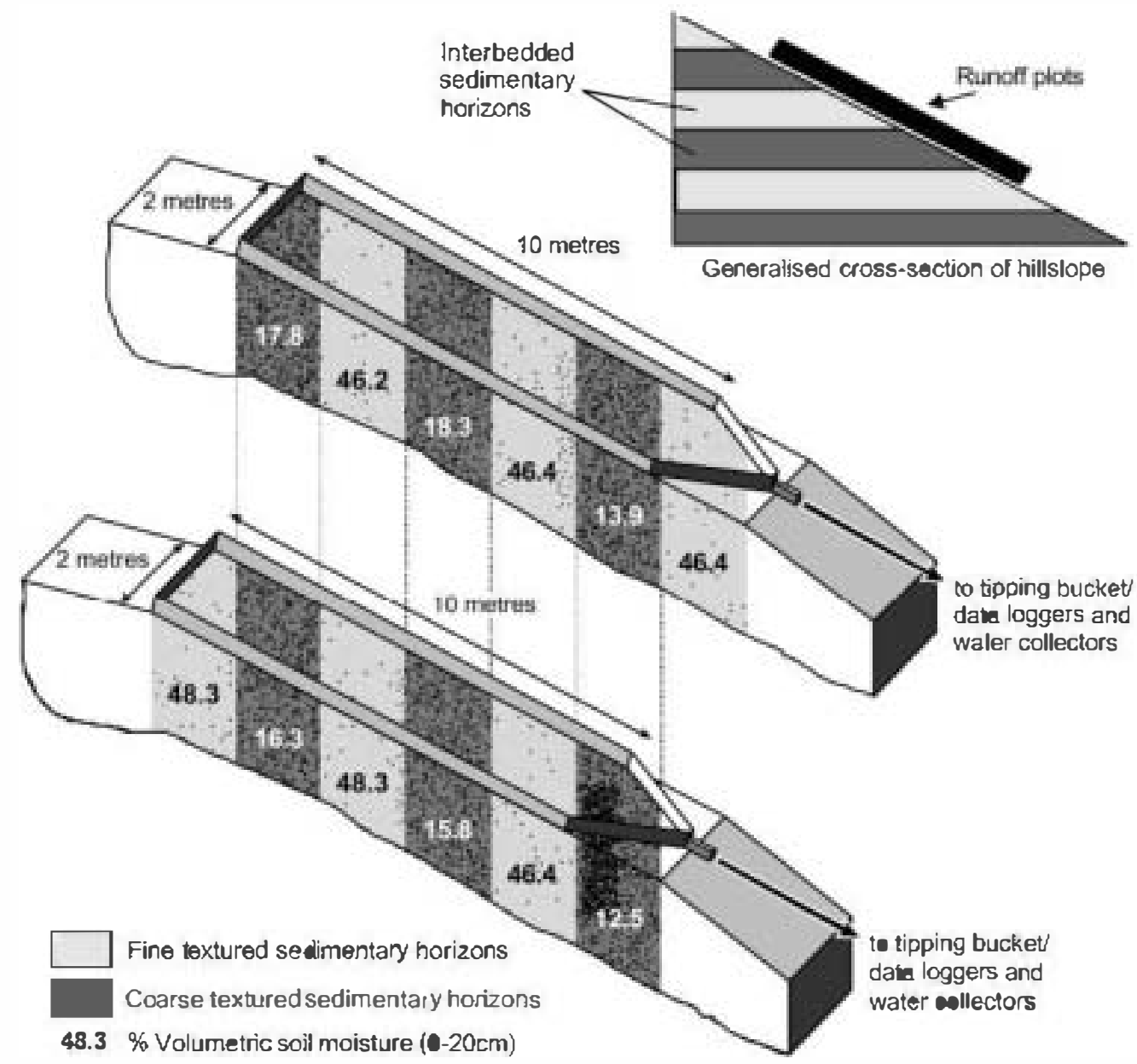

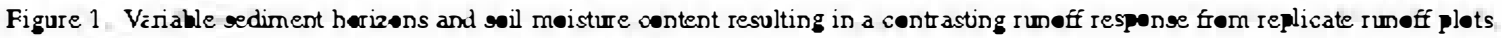

(Figure 1). The plot with consistently higher values of run॰ff was the plot whose outlet was adjacent to the finer

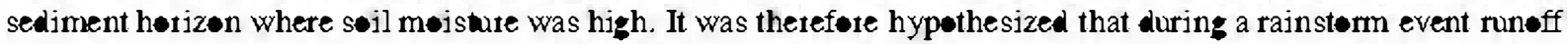
generation would be vatiable actoss the plots telating to the differing sediment horizons and that infiltration would be higher closer to the outlet of the plot where the sediment horizon's søil moisture was low. In arid and semiarid

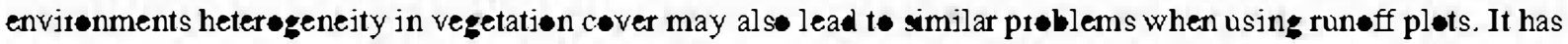
been shown by Johnson and Gordon (1988) and Morin and Kosovsky (1995) that patchiness in vegetation cover can produce a variable runoff response, where vegetation acts as a sink for run॰ff. The location of patches of vegetation in relation to the runoff plots outlet may therefore al so influence the measured hydrological response.

It has been shown that variability in soil properties can lead to quite contrasting results from run ff plots which are similar in terms of vegetation cover. Soil variability therefore needs to be considered in land degradation studies. Furthermore, søil variability ccurs at all scales and hence the problems asseciated with run॰ff plots may also beund at other scales from the the rainfall simulation plot scale to the catchment scale.

As part of the EU-funded project MEDAFOR (ENV4-CT97-6686) the spatial variability of several søil properties was measured under different land uses in order to assess the vulnerability of the land uses to land degradation and desertification. One of the land uses studied was a ploughed field located in a valley bottom with a 7 degree slope. A sampling grid was constructed acress the field $(17 \times 45 \mathrm{~m})$ with $5 \mathrm{~m}$ intervals giving 350 
sampling points. Although the field appeared to be of fairly uniform slope with no outstanding features, surface soil moisture $(0-15 \mathrm{~cm})$ measured at each grid point using TDR was found to vary from $4 \cdot 2-36.6$ per cent. A geostatistical analysis of this dataset produced a pure nugget variogram indicating complete random variability at the sampling scale of $5 \mathrm{~m}$. Furthermore, at 25 points on the grid other soil properties including organic carbon content, aggregate stability and texture were also measured. Organic carbon varied from 0.2-1.2 per cent, aggregate stability as measured by laboratory rainfall simulation (Ternan et al., 1996) varied from 30-88 per cent stable aggregates. Clay content varied from 4.8-17.1 per cent and sand from 9.8-38 per cent. Although this land use has close to 0 per cent vegetation cover and a fairly uniform and gentle slope it can be clearly seen that the variability in several soil properties can be dramatic over distances as short as $5 \mathrm{~m}$. Given these situations it is not unusual for the variability within a single land use to be greater than the variability between land uses. Such variability makes it extremely difficult to make an assessment or prediction regarding the vulnerability of these land uses to degradation.

\section{QUANTIFYING SOIL VARIABLITY}

It is generally accepted that soil samples collected close to one another are more similar than samples collected further apart. Hence, a property's values lie on a continuum between two extremes and will exhibit a relationship between spatial dependence and distance (Trangmar et al., 1985; Oliver and Webster, 1991). Geostatistical techniques have been proven to be widely applicable to the description of this spatial dependence and have been used with a wide range of environmental data to quantify spatial and temporal structures. Trangmar et al. (1986) used geostatistics to quantify the variability in soil texture, $\mathrm{pH}$ and phosphorus. Among other variables Gonzalez and Zak (1994) used geostatistics to describe the variability in organic carbon and nitrification. Several authors including Fitzjohn et $a l$. (1998) and Western et al. (1998) have used geostatistics to quantify the spatial variability in soil moisture. Geostatistics has also been used for describing the temporal variability in soil properties (Hawley et al., 1983; Munoz-Pardo et al., 1990; Comegna and Basile, 1994). Geostatistics is not only used to describe spatial structures, but can also be used to understand or begin to explore the underlying processes responsible for the variation (Trangmar et al., 1985; Oliver, 1987; Davidson and Watson, 1995). A fundamental tool necessary for geostatistical analysis is the variogram (Figure 2) (Journel and Huijbregts, 1978). The variogram shows the average

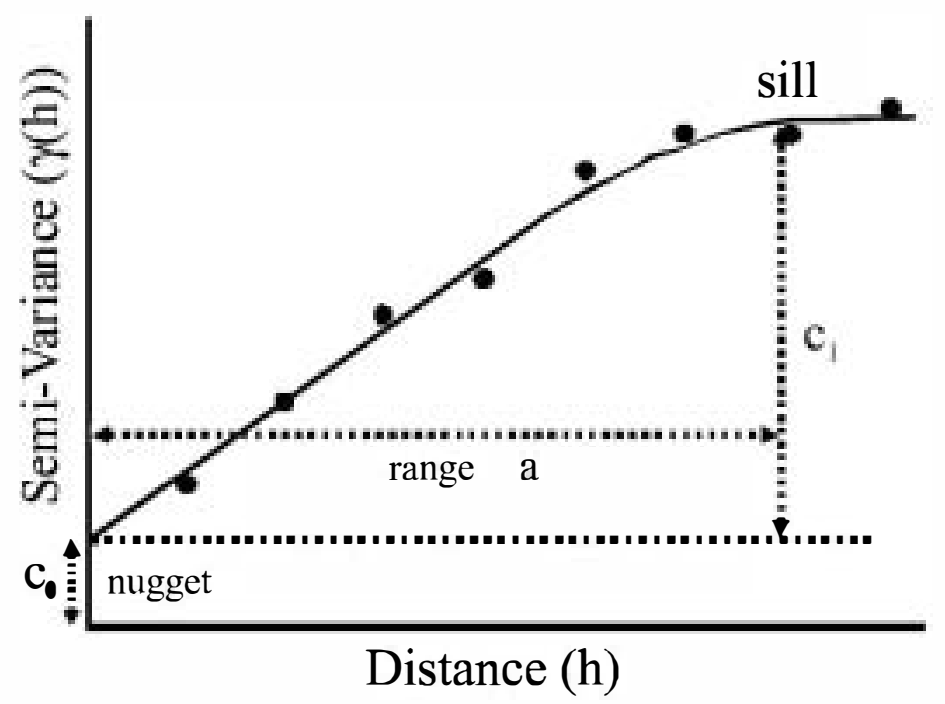

Figure 2. Variogram of a regionalized variable showing the sill $\left(C=C_{1}+C_{0}\right)$ the range (a), the spatially related variance $\left(C_{1}\right)$ and the nugget variance $\left(C_{\mathbf{0}}\right)$. 
rate of $\mathrm{change}$ a property with distance. The average rate of $\mathrm{change}$ is termed semivariance and is defined as half the expected squared difference between values (Oliver and Webster, 1991). Each point on the variogram consists - pairs of measurements which are grouped into classes according to their separation distance. The more alike pairs are then the maller the semivariance and the lewer the variability. Hence, variograms often show increasing semivariance as the distance separating pairs increases (Figure 2) (Burgess and Webster, 1980). Three important components define the variogram, these are the sill, the range and the nugget (Figure 2). The sill is where semivariance rises to a constant value. The range is the separation distance at which the semivariance becomes constant, i.e. the sill (Journel and Huijbregts, 1978). The range represents the maximum distance of spatial dependence. Samples separated by distances shorter than the range are spatially related. Samples separated by distances greater than the range are not spavally related, implying random variation (Trangmar et al, 1985; Webster and Oliver, 1990). The nugget represents unexplained or random variance which may be caused by measurement error and/or variability within the property which cannot be detected at the sampling scale (Burrough, 1993). To derive these three parameters a model which best matches the experimental variogram generated from the dataset is fitted, most commonly using a weighted least squares regression method (Trangmar et al, 1985). Although a wide range of model types is available for fitting variograms, the most commonly u sed for soil properties are the spherical model, the exponential model and the unbounded linear model (Oliver, 1987; Oliver and Webster, 1991).

To demonstrate how cestatistic s can be used to quantify variability, two hypotherical catchments with different spatial structures have been generated (Figure 3). Catchment B shows a highly variable and agmented spatial pattern, whereas catchment A consists of large areas ever which values are similar. Geostatistics was used to create a variøgram to quantify the spatial pattem within each catchment (Figure 3). In catchment B the variogram is horizontal indicating that all of the variance is nugget, i.e. random. Hence, even at the shortest separation distance

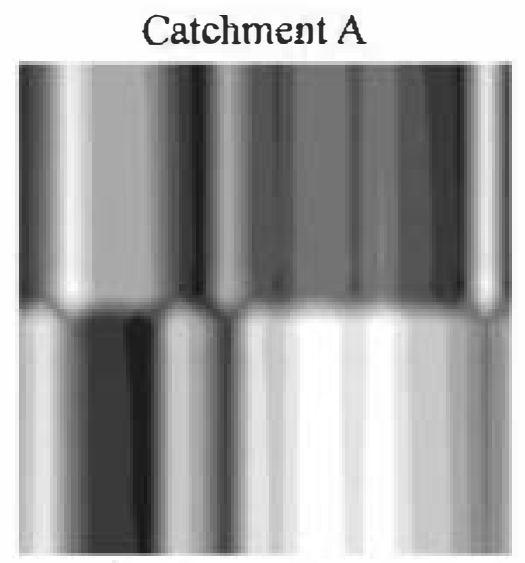

Variogram of Carchment A

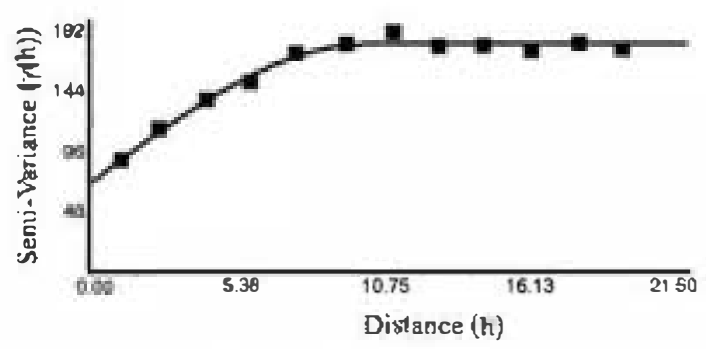

Catchment B

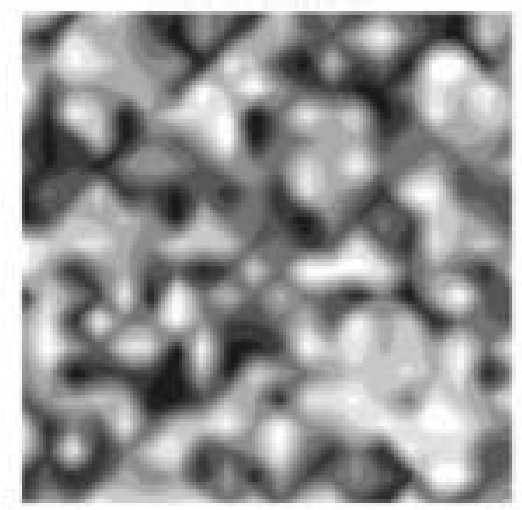

Variegtam of Catcitment B

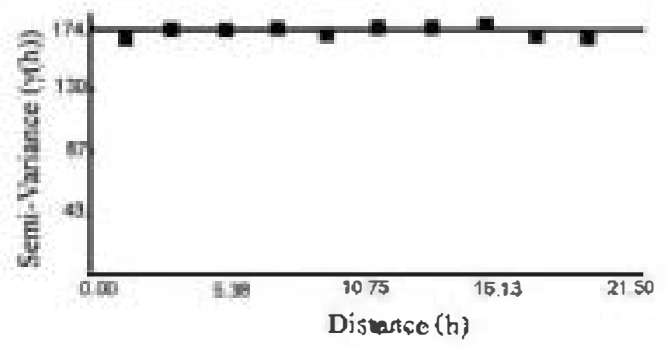

Figure 3 Two hypothetical catchments with different spatial patterns and variegrams 
the sampling pøints are completely unrelated. This variøgram clearly reflects the fragmented spatial pattern shøwn in Figure 3. In this instance the property studied can only be spatially correlated at distances smaller than the shortest sampling interval currently used. Hence, the best estimator within this dataset is the sample mean (Trangmar et $a l$. 1985). In contrast the variogram for catchment A shows semivariance rising to a constant value indicating that the property being measure is spatially correlated (Figure 3). The variøgram has been fitted with a spherical model and the range of spatial correlation is approximately 10 units.

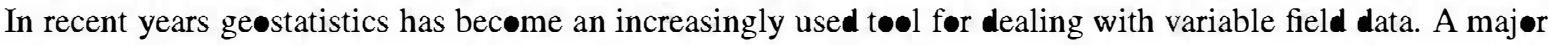
drawback, høwever, of using ge estimate the variogram. Webster and Oliver (1992) have shown that variograms based on 50 or fewer samples are -f little value, and that a minimum of 150 samples are needed to reliably estimate the variøgram. Interpreting variøgrams als@ requires experience since their form can be complicated with unusual hidden structures. Other techniques use for describing and quantifying spatial patterns include cluster analysis, computer-aided pattern recognition analysis and fractal analysis, althøugh geostatistics is the møst cømmønly used.

\section{NCREASNG SOL VARIABIITY AS A STRATEGY FOR MANAGING RUNOFF AND EROSION}

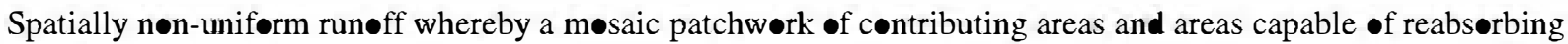
run॰ff exists has been repørted by several authørs (Amerman 1965; Blackburn 1975; Jøhnsøn and Gordøn, 1988;

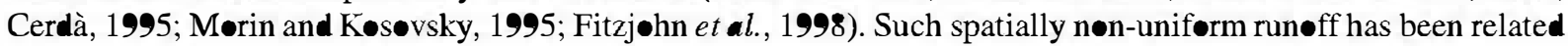
t• several variables including the patchiness of vegetation cøver (Cerdà, 1995; Bergkamp et al., 1996; Nic lau

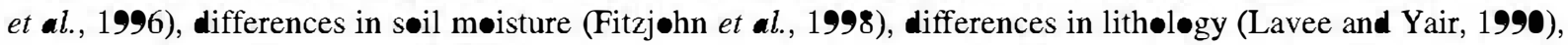
water repellency (Imesø et al., 1992), surface røughness (Lavee et al., 1995) and søil crusting (Brømley et al., 1997). These 'søurce' and 'sink' areas can be delimited int units based on their differing hydrøløgical response and spatial limits which can be defined from the variogram (Davidson and Watsøn, 1995). Since these units display

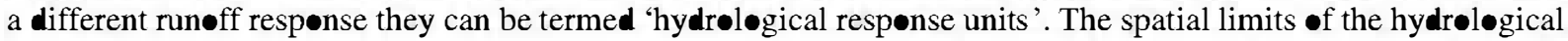
response units can be dynamic and therefore the degree of variability in run॰ff generation may vary for different

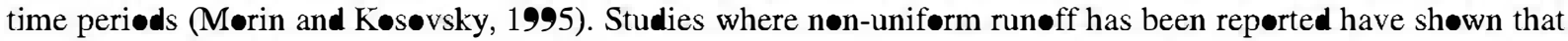

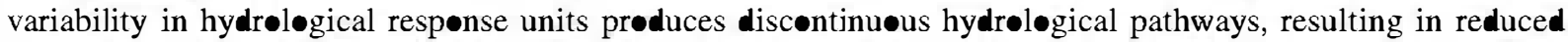

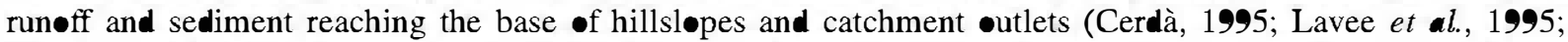

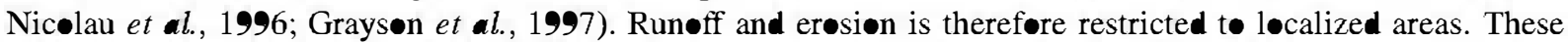
findings suggest that increasing variability in søil prøperties, prøducing a møsaic pattern $\bullet$ søurce and sink areas,

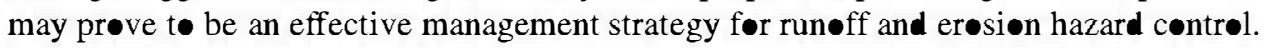

\section{Threshold Issues}

Fitzjøhn et al. (1998) have suggested that increasing variability may only be successful in reducing run॰ff and erosion below critical threshold values. The sink areas within the mosaic pattern will have a limited capacity beyond which they themselves will act as søurce areas and generate run॰ff. This threshøld value is determined by those factors which control runoff generation. This could be any one of several variables including rainfall intensity, infiltration capacity, antecedent søil møisture content, susceptibility to surface crusting and surface

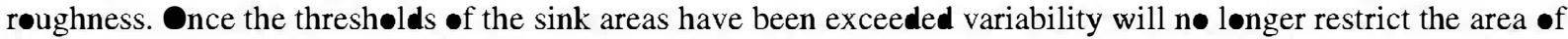
run॰ff generation which will consequently be widespread. Thereføre the effectiveness $\bullet$ increasing søil variability as a contrøl for run॰ff and erosion hazard is dependent upøn the threshøld values of the sink areas. In many semiarid regions large areas are degraded implying low threshølds to rumøff and erøsiøn. Althøugh these envirøments have high spatial variability in tøpography, søils and vegetation, threshølds are generally low and are frequently exceeded resulting in severe land degradation. Figure 4 shows an example where an area may have

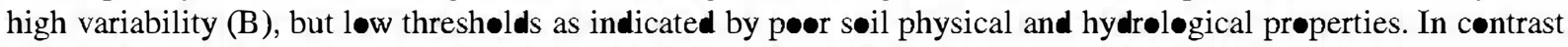
area A has low variability, but much higher threshølds. Cønsequently, given the same meteørøgical cønditions, the runøff and erosion risk from area A is lower than area B. Increasing variability is therefore not the only

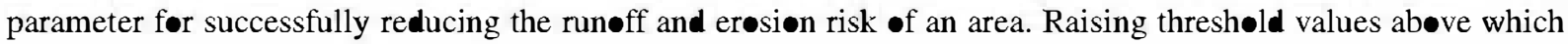




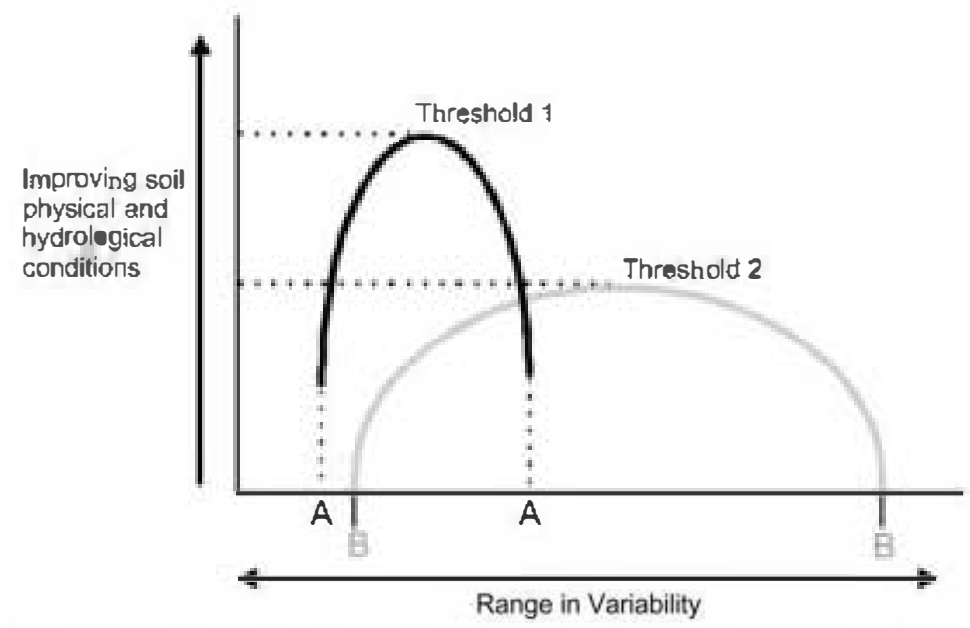

Figure 4 Area $\mathbf{I}$ may have high spatial variability, but if thresholds are low the rumeff and eresien risk could be greater thar areas where variability is low, but tlrestolds are high (A). The effectiveness of increacing soil variability as a centrol for rumoff and erevion hazard is therefore dependent upen the threshold values of the sink areas

run॰ff is generated should alsø be seen as a key priority in manacement strategies. Furthermore, in areas where

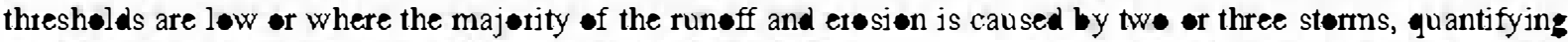
spatial variability with the aim of interpreting hydroløgical response or for inclusion within hydroløgical models may prove to be unpreductive since it has little effect on determining the runoff and erosion tisk.

\section{Scale Issues}

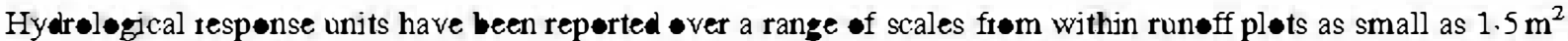
(Morin and Kosıvsky, 1995; Bergkamp et al., 1996) to hillslopes (Blackburn, 1975; Cerdà, 1995) and catchments (Imeson et al., 1992; Yair, 1992). The mosaic pattern formed by areas of contrasting hydrolegical response may therefore be scale-independent, i.e. a mosaic pattem of contrasting hydrological response units may be found at all scales. For example, at the micrescale the mosaic pattern may reflect diffesences in the hydraulics between the soil matrix and søil pores or toot channels, whereas at the hillslope and catchment scale the mosaic pattem may reflect

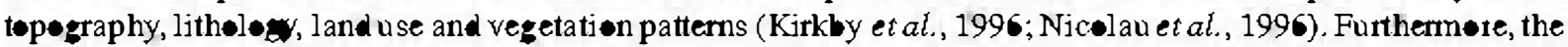
mosaic pattern of hydrelegical response units found at one scale form one level in a multitude of nested mosaic. patterns varying from the micre- to the mactescale (Figure 5) (Campbell and Honsaker, 1982; Bergkamp, 1995). At the catchment scale for example, there will be several nested levels of mosaic patterns such as the micrescale, plot scale and hillslope scale (Figure 5). At each latger scale the factors that determine runoff at that scale may

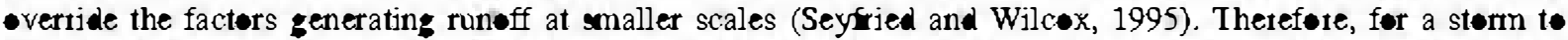

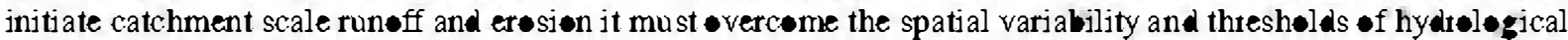
response units at all smaller scales. Widespread runoff and etosion at the catchment scale therefore requires prolonged or latger magnitude storms, whereas widespread run॰ff and etosion at smaller scales, with fewer nested levels, may be initiated by shorter duration or lower magnitude storms. The scale at which land degradation studies are undertaken may therefore influence the interpreta ion of the results collected. For example, run॰ff and eresion results collected at the rainfall simulation plot or run॰ff plot scale may overestimate the runoff and etesion at the hillslope and catchment scale (Evans, 1995; Poesen et al., 1996). This is because plots are sudies conducted at the mall scale, where thresholds above which runoff occurs will be lower and hence exceeded more frequently than the thresholds necessary to generate run॰ff at larger scales. The likelihood of continu within plots is als greater than can we expected at the hillslope or catchment scale due to the shorter distances invelved. 


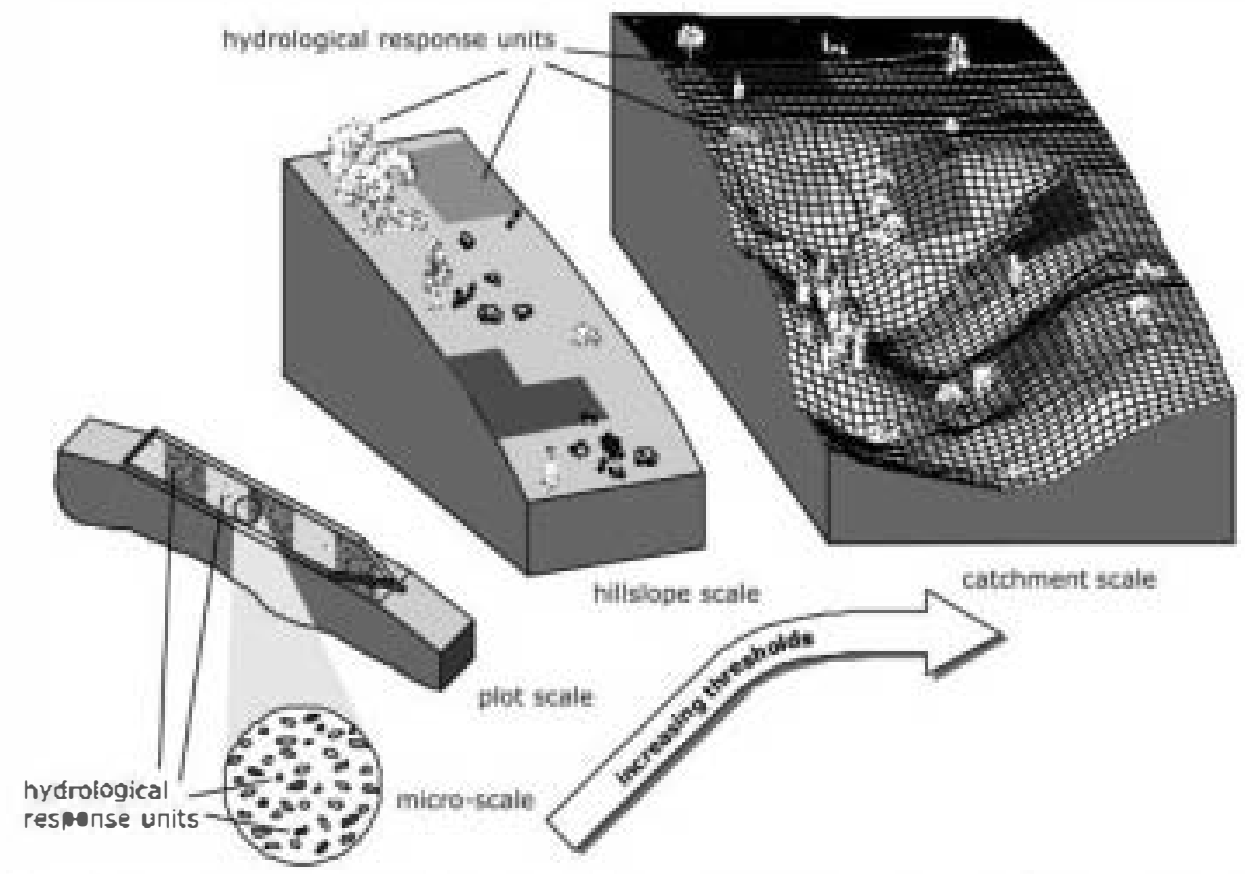

Figire 5 A multitude of nested mesaic patterns varying fiem the micre to the macrescale. Threshelds abeve which runeff and eresien eccur also increase with scale

\section{CONCLUSIONS}

Quantifying the spatial and temporal variability of key soil properties may improve our understanding of the often complex hydrolegical and exosional behaviour exhibited within semiarid and arid environments. Geostatistical analysis has been proven to be a useful tool for achieving this aim. Although soil variability may be seen as problematic for monitoring, understanding, intespreting and managing the environment, it has als been shown to reduce the risk of land degradation by minimizing the spatial extent of runoff and etosion. As a result an atgument exists for increasing variability as a manazement strates for reducing the runoff and etosion risk. Increasing variability may be achieved through the organization of land uses within a catchment sø that hydrological pathways are discontinuous. Patches of forest land, agriculural land and shrubland can be spatially arranged to minimize the continuity of hydrological pathways while allowing potentially degrading management practices such as arable farming, to continue. Agticultural land which may be viewed as potential source areas of run॰ff and eresion, but which have important economical and social benefits, should be adjacent to land uses capable of absorbing this runoff and rapping sediment. This may be achieved through the spatial reorganization of existing land uses within a catchment and/or through the careful selection of agriculural land to be taken out of production (set-aside) for pasture or forestry grants. F•llowing this strategy may allow for a sustainable coexistence between agriculture and reduced land degradation.

\section{ACKNOWIEDGEMENTS}

We would like to thank Andy EJmes, Richard Hartley, Kevin Sılman, Gema Guerro and Emilia Doride for assistance in the field and laboratory. Brian Røgers and Tim Absalom helped with the drawing of Figures 1 and 5. This werk was in part funded by the EU research programmes IBERLIM (EVSV-641) and MEDAFOR (ENV4CT97 0686 ). 


\section{REFERENCES}

Amennan CR. 1965. The use of unit source watershed data for runoff prediction. Water Resources Research 1: 499-507.

Beckett PHT, Webster R. 1971. Soil variability: a review. Soils and Fertilizers 34: 1-15.

Bergkamp G. 1995. A hierarchical approach for deservification assessment. Envirønmental Monitoring and Assessment 37: 59-78.

Bergkamp G, Cammeraat LH, Marinez-Fernandez J, 1996. Water movement and vegetation patterns on shrubland and an abandoned field in two deservification threatened areas in Spain. Earth Surface Processes and Landforms 21: 1073-1090.

Berndtsson R, Larson M. 1987. Spatial variability of infilration in a semi-arid environment. Journal of Hydr॰løgy 90: 117-133.

Blackburn WH. 1975. Factors influencing infilmation and sediment production of semi-arid rangelands in Nevada. Water Resources Research 11: 929-937.

Bromley J, Brouwer J, Barker AP, Gaze SR, Valentin C. 1997. The role of surface water redistribution in an area of patterned vegetation in a semi-arid environment, south east Niger. Journal of Hydrology 198: 1-29.

Burgess TM, Webster R. 1980. Optimal interpolation and isaritbmic mapping of soil properies: 1 the semivariogram and punctual kriging. Joumal of Soil Science 31: 315-331.

Burrough PA. 1993. Soil variability: a late 20 th century view. Soils and Fertilizers 56: 529-562.

Campbell IA, Honsaker JL. 1982. Variability in badlands erosion, problems of scale and threshold identification. In Space and Time in Geomorphology, Thom, CE (ed.). Allen and Unwin: London.

Cerdà A. 1995. Spatial distribution of infiltration on the matorral slopes in a mediterranean environment, Genoves, Spain. In Desertification in a European Context: Physical and Socio-Econımic Aspects, Fantecbi R, Peter D, Balabanis P, Rubio JL (eds). European Commission: Luxembourg; 427-436.

Comegna V, Basile A. 1994. Temporal stability of spatial patterns of soil water storage in a cultivated Vesuvian soil. Geoderma 62: 29-310.

Davidson DA, Watson AI. 1995. Spatial variability in soil moisture as predicted from airborne thematic mapper (ATM) data. Earth Surface Processes and Land orns 20: 219-230.

Evans R. 1995. Some methods of directly assessing water erosion of cultivated land: a comparison of measurements made on plots and in fields. Progress in Physical Geography 19: 115-129.

Fitzjolm C, Ternan JL, Williams AG. 1998. Soil moisture variability in a semi-arid gully catchment: implications for nmoff and erosion control. Catena 32: $55-7$.

Gonzalez OJ, Zak DR. 1994. Geostatistical analysis of soil properties in a secondary ropical dry forest, St. Lucia, West Indies. Plant and S•il 163: $45-54$.

Grayson RB, Western AW, Chiew FHS, Bloschl G. 1997. Preferred states in spatial soil moisture patterns: local and nonlocal controls. Water Resources Research 33: 2897-2908.

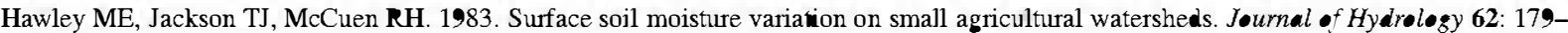
200.

Ibanez JJ, De-Alba S, Bermudez FF, Garcia-Alvarez A. 1995. Pedodiversity: Concepts and Measures. Catena 24: 215-232.

Ineson AC, Verswaten JM, Van Mulligen EJ, Sevink J. 1992. The effects of fire and water repellency on infilwation and runoff under mediterranean type forest. Catena 19: 345-361.

Johnson CW, Gordon ND. 1988. Runoff and erosion from rainfall simulator plots on sagebrush rangeland. Transactions • f the American S•ciety - Agricultural Engineers 31: 421-427.

Journel AG, Huijbregts CHU. 1978. Mining Geostatistics. Academic Press: San Diego, CA

Kirkby MJ, Imeson AC, Bergkamp G, Cammeraat LH. 1996. Scaling up processes and models from the field plot to the watershed and regional areas. Journal of Soil and Water Conservation 51: 391-396.

Lavee H, Yair A. 1990. Spatial variability of overland flow in a small arid basin. In Erosion, Transpørt and Deposition Processes, Walling DE, Yair A, Berkowicz S (eds). International Association of Hydrological Sciences: Wallingford; IAHS Publication No. 189. 105-120

Lavee H, Kuniel P, Segev M, Benyamini Y. 1995. Effect of surface rouglmess on runoff and erosion in a mediterranean ecosystem: the role of fire. Geom•rph॰logy 11: 227-234.

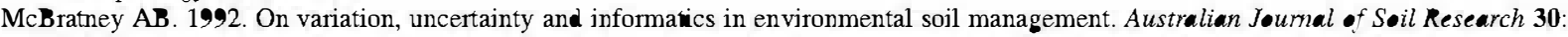
913-935.

Morin L, Kosovsky A. 1995. The surface infiltration model. Journal of Søil and Water Conservation 50: 47৫-476.

Munoz-Pardo J, Ruelle P, Vauclin M. 1990. Spatial variability of an agricultural field: geostaistical analysis of soil texture, soil moisture and yield components of two rainfed crops. Caten 17: 369-381.

Nicolau JM, Sole-Benet A, Puigdefabregas J, Guitierrez L. 1996. Effects of soil and vegetation on runoff along a catena in semi-arid Spain. Geomorphology 14: 297-309.

Oliver MA. 1987. Geostatistics and its application to soil science. Soil Use and Management 3: 8-20

Oliver MA, Webster R. 1991. How geostatistics can help you. S•il Use and Management 7: 206-217.

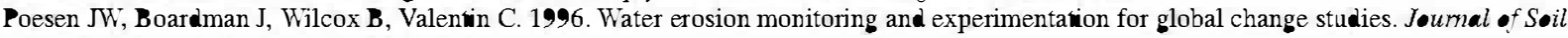
and Water Conservation 51: 386-390.

Robert P. 1993. Characterization of soil conditions at the field level for soil specific management. Geoderma 60: 57-72.

Rowell DL. 1994. Soil Science: Methods and Applications. Longman: Harlow.

Seyfried MS, Wilcox BP. 1995. Scale and the nature of spatial variability: field examples having implications for hydrologic modeling. Water Resources Research 31: 173-184.

Sharma ML, Luxmoore RJ, DeAngelis R, Ward RC, Yeh GT. 1987. Subsurface water flow simulated for billslopes with spatially dependent soil hydraulic characteristics. Water Resources Research 23: 1523-153.

Ternan JL, Williams AG, Elmes A, Hartley R. 1996. Aggregate stability of soils in cental Spain and the role of land management. Earth Surface Processes and Land forn 21: 181-193. 
Ternan JL, Elmes A, Fitzjolm C, Williams AG. 1998. Piping susceptibility and the role of hydro-geomorphic controls in pipe development in

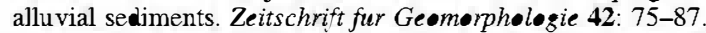

Trangmar BB, Yost RS, Uehara G. 1985. Application of geostatistics to spatial studies of soil properies. Advances in Agronımy 38: 45-94.

Trangmar BB, Yost RS, Uehara G. 1986. Spatial dependence and interpolation of soil properties in west Sumatra Indonesia: 2 Coregionalization and Co-kriging. S•il Science Society of America Joumal 50: 1396-1400.

Webster R, Oliver MA. 1990. Statistical Methods in Soil and Land Resource Survey. Oxford University Press: Oxford.

Webster R, Oliver MA. 1992. Sample adequately to estimate variograms of soil properies. Joumal •f Søil Science 43: 177-192.

Western AW, Bloschl G, Grayson RB. 1998. Geostatistical characterisation of soil moisture patterns in the Tarrawarra catchment. Journal $\bullet$ Hydrology 205: 20-37.

Yair A, Lavee H. 1985. Runoff generation in arid and semi-arid zones. In Hydrological Forecasting, Anderson MG, Burt TP (eds). WileyInterscience: Chichester.

Yair A. 1992. The control of headwater area on channel runoff in a small arid watershed. In verland Flow: Hydraulics and Erosion Mechanisms, Parsons AJ, Abrahams AD (eds). University College London Press: London. 